\title{
Antidiarrhoeal activity of the methanol stem-bark extract of Annona senegalensis Pers. (Annonaceae)
}

\author{
M.M. Suleiman, T. Dzenda, C.A. Sani \\ Department of Physiology and Pharmacology, Faculty of Veterinary Medicine, Ahmadu Bello \\ University, Zaria, Nigeria \\ Phytomedicine Programme, Department of Paraclinical Sciences, Faculty of Veterinary \\ Science, University of Pretoria, Private Bag X04, Onderstepoort 0110, South Africa
}

With 1 table and 5 figures

\section{Abstract}

Aim of the study: To investigate the antidiarrhoeal properties of the stem-bark extract of Annona senegalensis, using both in vivo and in vitro models.

Materials and methods: Swiss albino mice were used to investigate the acute oral toxicity of the extract. The extract was administered orally to mice fed with charcoal meal in order to investigate intestinal transit time. The effect of the extract on contraction of isolated rabbit jejunum and the responses of the tissue to acetylcholine and histamine were also investigated.

Results: The extract was safe at doses up to $5000 \mathrm{mg} / \mathrm{kg}$. The extract at the dose of 10 $\mathrm{mg} / \mathrm{kg}$ significantly $(p<0.05)$ decreased intestinal transit time at concentrations of $0.2-3.2$ $\mathrm{mg} / \mathrm{ml}$, the extract attenuated spontaneous contractions of the isolated rabbit jejunum, and those induced by acetylcholine in a concentration-dependent fashion.

Conclusion: The extract decreased intestinal transit time by attenuating the spontaneous contractions of the intestine, thus the study provided a scientific basis for the use of Annona senegalensis stem bark extract in the treatment of diarrhoea.

Keywords: Annona senegalensis; Antidiarrhoeal; Gastrointestinal transit time; Rabbit jejunum; Toxicity studies

\section{Introduction}

Diarrhoea has long been recognized as one of the most important health problems in developing countries (Snyder and Merson, 1982). It is defined as an increase in the frequency, fluidity, or volume of bowel movements and is characterized by increased frequency of bowel sound and movement, wet stool, and abdominal pain (Fontaine, 1988). In clinical terms it is used to describe increased liquidity of stool, usually associated with increased stool weight and frequency (Longe and Dipiro, 1992).

In Nigeria, diarrhoea remains the number one killer disease among children aged 1-5 years, and worldwide the disease accounts for 4-5 million deaths among humans annually (Audu et al., 2000).Treatment of diarrhoea is generally non-specific and is usually aimed at reducing the discomfort and inconvenience of frequent bowel movements (Brunton, 1996). To overcome the menace of diarrhoeal diseases in developing countries, theWorld Health Organisation (WHO) has included a programme for the control of diarrhoea, which involves the use of traditional herbal medicine (Snyder and Merson, 1982). Several plants have been reported to be used in treating and managing diarrhoeal diseases (Agunu et al., 2005). Annona senegalensis Pers (Annonaceae) popularly called "gwandar daaji" in the Hausa language is found widely distributed in central and west Africa. The plant possesses several medicinal uses. The boiled root-bark is used by Hausas of northern Nigeria for intestinal troubles and the bark is chewed in Senegal for stomach ache (Dalziel, 1955). This plant has been used as an anthelmintic by local livestock farmers in Nigeria (Ibrahim et al., 1983; Nwude and Ibrahim, 1980). The stem, root and bark are used to treat diarrhoea and gastrointestinal troubles (Burkill, 1985), while the stem bark and leaves are used for the treatment of skin cancer and leukemia (Abubakar et al., 2007). 
In the study described in this report, the antidiarrhoeal effect of methanol extract of the stem bark of Annona senegalensis, using both in vivo and in vitro experimental models was evaluated. In addition, an effort was made to assess the safety of the plant extract in vivo.

\section{Materials and methods}

\subsection{Plant material}

\subsubsection{Collection of plant material}

Fresh stem bark of Annona senegalensis was collected at the main campus of Ahmadu Bello University (A.B.U.), Samaru, Zaria, Nigeria. The plant was identified taxonomically and authenticated by Mr. M.D. Musa at the Herbarium of the Department of Biological Sciences, A.B.U., Samaru, Zaria, Nigeria. A specimen was deposited in this Herbarium, with voucher number 900167.

\subsubsection{Preparation of plant material}

The stem bark of the plant was air-dried and powdered using a clean mortar and pestle. The powdered bark was cold-extracted in a percolator (Brain and Turner, 1975) using methanol as solvent, mixed in a ratio of 1:3 (bark:methanol). Two hundred and ten grams of the powdered stem bark was packed into a cylindrical percolator and macerated for $48 \mathrm{~h}$ to obtain a darkbrown solid residue. The methanol extract yield of this plant part was $9.2 \%(\mathrm{w} / \mathrm{w})$. The extract was dissolved in freshly prepared sterile normal saline at a concentration of $50 \mathrm{mg} / \mathrm{ml}$.

\subsection{Animals}

Rabbits (crossbreed) of both sexes weighing between 2.2 and $2.5 \mathrm{~kg}$ were purchased from the National Animal Production Research Institute, Shika, Zaria, Nigeria. Swiss albino mice of both sexes were purchased from the Department of Veterinary Public Health and Preventive Medicine, Ahmadu Bello University, Zaria. All animals were kept in cages and allowed to acclimatize for 2 weeks in our laboratory in the Department of Veterinary Physiology and Pharmacology, Ahmadu Bello University, Zaria, before experiments were started. Wood shavings were used as bedding and were changed three times per week. The animals were fed with standard pelleted diet and water was given freely. All experimental protocols described in this study were approved by the Ethics Review Committee for Animal Experimentation of Ahmadu Bello University, Zaria (ABUVM2006).

\subsection{Experimental procedures}

\subsubsection{Phytochemical screening}

The methanol extract of the stem bark of Annona senegalensis was evaluated for the presence of flavonoids, tannins, alkaloids, saponins, glycosides and sterols/triterpenes using methods described by Brain and Turner (1975).

\subsection{Acute toxicity test}

The method described by Lorke (1983) with slight modification in the number of animalswas used to determine the safety of the extract. Briefly, apparently healthy Swiss albino mice weighing 22-23 g were divided into groups of three mice in each cage. The extract was dissolved in normal saline and administered via the oral route. The first batch of mice consisting of three groups received 10,100 and $1000 \mathrm{mg} / \mathrm{kg}$ of the extract. Similarly, the second batch was dosed with 1600,2900 and $5000 \mathrm{mg} / \mathrm{kg}$. The general behaviour of mice was observed continuously for $1 \mathrm{~h}$ after the treatment and then intermittently for $4 \mathrm{~h}$, and thereafter over a period of $24 \mathrm{~h}$. The mice were further observed for up to 14 days following treatment for any signs of toxicity, and mortality.

\subsection{Spasmolytic effects}

\subsubsection{Effect on gastrointestinal transit time}

The mice were fasted for $12 \mathrm{~h}$ before the commencement of the experiment and were randomly allocated into six groups of five mice each. Animals in the first, second, third and 
fourth group were dosed orally with the extract at 10,100, 1000 and $2900 \mathrm{mg} / \mathrm{kg}$, respectively. The mice in group 5 received $5 \mathrm{ml} / \mathrm{kg}$ of normal saline, while those in group 6 were dosed with a standard antidiarrhoeal agent (loperamide) at a dose of $1 \mathrm{mg} / \mathrm{kg}$. One hour later each animal was dosed orally with charcoal meal as a marker diet (Aye-Than et al., 1989). One hour after the charcoal meal was given, all the mice were sacrificed by euthanasia in a chloroform chamber, their abdomens were cut open and their intestines were carefully removed from the cardia to the anus. The intestines were immediately immersed in formalin to arrest peristalsis. Thereafter, the intestines were washed in clean tap water. The distance the meal traversed through the intestine as shown by the charcoal meal front was measured in each individual mouse.

The percentage inhibition of gastrointestinal transit of the charcoal meal by loperamide and the extract was calculated as a function of the negative control using the following formula: percentage inhibition $=\left[N-{ }^{n} N\right] \times 100$ where $N$, mean length traversed by charcoal meal in non-treated mice and $n$, mean length traversed by charcoal meal in treated mice.

\subsubsection{Effect on isolated rabbit ileum}

A rabbit was fasted for $12 \mathrm{~h}$ before the experiment, and thereafter it was sacrificed by a blow on the head and exsanguinated. Segments of the ileum, about $2 \mathrm{~cm}$ long were cut.

Remaining intestinal contents were removed by flushing using Tyrode's solution of the following composition (mM): $\mathrm{NaCl}(136.8), \mathrm{KCl}(2.7), \mathrm{CaCl}_{2}$ (1.3), $\mathrm{NaHCO}_{3}$ (11.9), $\mathrm{MgCl}_{2}$ (0.5), $\mathrm{Na}_{2} \mathrm{PO} 4(0.45)$ and glucose (5.5)] at a temperature of $37\left( \pm 1{ }^{\circ} \mathrm{C}\right)$, and aerated with air. The ileum was suspended in a $25 \mathrm{ml}$ organ bath containing Tyrode's solution. A load of $0.5 \mathrm{~g}$ was applied and $1 \mathrm{~h}$ equilibration time was allowed during which the physiological solution was changed every $15 \mathrm{~min}$. Changes in the tension were recorded with Ugo Basile microdynamometer with isotonic transducer (Amos et al., 1998).

The responses of the tissue to serial concentrations of acetylcholine $\left(2.0 \times 10^{-9}, 4.0 \times 10^{-9}\right.$, $8 \times 10^{-9}$, and $\left.1.6 \times 10^{-8}\right)$, histamine $\left(2.0 \times 10^{-6}, 4.0 \times 10^{-6}, 8.0 \times 10^{-6}, 1.6 \times 10^{-5}\right.$, and $\left.3.2 \times 10^{-5} \mathrm{~g} / \mathrm{ml}\right)$ and the extract $\left(4.0 \times 10^{-4}, 8.0 \times 10^{-4}, 1.6 \times 10^{-3}, 3.2 \times 10^{-3}\right.$, and $\left.6.4 \times 10^{-3} \mathrm{~g} / \mathrm{ml}\right)$ were recorded. Furthermore, a fixed concentration of acetylcholine $\left(8.0 \times 10^{-9} \mathrm{~g} / \mathrm{ml}\right)$ and histamine $\left(4.0 \times 10^{-6}\right.$ $\mathrm{g} / \mathrm{ml})$ were interacted with varying concentrations of the extract $\left(4.0 \times 10^{-4}, 8.0 \times 10^{-4}, 1.6 \times 10^{-3}\right.$, $3.2 \times 10^{-3}$, and $6.4 \times 10^{-3} \mathrm{~g} / \mathrm{ml}$ ). Each concentration tested was allowed a contact time of $1 \mathrm{~min}$ followed by washing three times. A resting period of $15 \mathrm{~min}$ was allowed before the next addition.

\subsection{Statistical analysis}

The results on gastrointestinal transit time were expressed as mean \pm S.E.M. Differences between means were analysed using one-way analysis of variance (ANOVA). Values of $p<$ 0.05 were considered statistically significant.

\section{Results}

\subsection{Phytochemical screening}

The methanol extract of Annona senegalensis stem bark was positive for reducing sugars, tannins, saponins, flavonoids, sterols and glycosides.

\subsection{Acute toxicity tests}

The extract at doses of $10,100,1000 \mathrm{mg} / \mathrm{kg}$ and second dose levels of 1600, 2900 and 5000 $\mathrm{mg} / \mathrm{kg}$ produced no mortality or apparent toxic signs.

\subsection{Spasmolytic effects}

\subsubsection{Gastrointestinal tract transit time}

The results are shown in Table 1 . The extract at the dose of $10 \mathrm{mg} / \mathrm{kg}$ and loperamide significantly $(p<0.05)$ reduced the length covered by the charcoal meal when compared with normal saline treated animals. However, no significant difference was observed with the extract at doses of 100,1000 and $2900 \mathrm{mg} / \mathrm{kg}$. Indeed the extract at higher doses produced an enhanced peristaltic effect. 


\subsubsection{Effect on isolated rabbit ileum}

The extract of Annona senegalensis, at increasing concentrations, inhibited spontaneous contractions of the isolated rabbit ileum in a concentration-dependent fashion (Fig. 1). Application of acetylcholine to the bathing medium of the isolated rabbit ileum, at increasing concentrations greatly increased the contractions of the tissue (Fig. 2). Similarly, histamine concentration-dependently enhanced the contractile response of the isolated rabbit ileum (Fig. 3). The extract concentration-dependently $\left(4.0 \times 10^{-4}, 8.0 \times 10^{-4}, 1.6 \times 10^{-3}\right.$ and $3.2 \times 10^{-3}$ $\mathrm{g} / \mathrm{ml}$ ) reduced the contractile effect of Ach $\left(8.0 \times 10^{-9} \mathrm{~g} / \mathrm{ml}\right)$ on the isolated rabbit ileum (Fig. 4). However, the contractile effect of histamine on the tissue was inhibited by the extract only at higher concentrations $\left(8.0 \times 10^{-4} \mathrm{~g} / \mathrm{ml}\right.$ and $\left.1.6 \times 10^{-3} \mathrm{~g} / \mathrm{ml}\right)$ (Fig. 5).

\section{Discussion}

The extract of Annona senegalensis did not show any toxic effects because doses $<5 \mathrm{~g} / \mathrm{kg}$ did not cause any death or alter the behaviour of normal animals. According to Lorke (1983), any substance that is not toxic at $5000 \mathrm{mg} / \mathrm{kg}$ is considered relatively safe. The plant extract was, therefore, considered to be safe at doses $\leq 5000 \mathrm{mg} / \mathrm{kg}$.

Phytochemical analysis revealed the presence of reducing sugars, tannins, saponins, flavonoids, sterols and cardiac glycosides in the stem bark of Annona senegalensis. Sofowora (1993) reported the presence of alkaloids as well as saponins, tannins, and cardiac glycosides in the methanol leaf extract of the plant. Flavonoids and sugars obtained from selected traditional medicinal plants in Bangladesh and some parts of the world, were reported by Rahman and Wilcock (1991), and Palombo (2005), respectively, and were shown to exhibit antidiarrhoeal properties. Longanga Otshudi et al. (2000) screened a number of medicinal plants and showed that antidiarrhoeal activity of those plants were due to tannins, alkaloids, saponins, flavonoids, sterols, triterpenes and reducing sugars contained in them. Flavonoids have been shown to attenuate contraction of guineapig ileum induced by some spasmogens (Macander, 1986), and inhibit small intestinal transit (Viswanathan et al., 1984). In this study, the antidiarrhoeal effect of Annona senegalensis at a dose of $10 \mathrm{mg} / \mathrm{kg}$ was found to be similar to loperamide (a standard antidiarrhoeal agent) (Rang et al., 2003). Loperamide though appears to be 10 times more potent antidiarrhoeal agent that the extract, the lowpotency exhibited by Annona senegalensis could be as a result of its crude nature. Loperamide, however, is used in its pure form. Surprisingly, the extract when administered at higher doses (>100 mg/kg) caused increased peristalsis in charcoal fed animals. Similarly, morphine when administered at a lower dose causes decreased intestinal smooth muscle tone leading to constipation. However, when given at relatively higher doses to a dog it causes persistent spasmogenic effect upon the intestinal smooth muscle by direct action, partly by cholinergic and partly by histaminergic mechanisms (Branson and Gross, 2001). Perhaps similar mechanisms could explain the action of the extract of Annona senegalensis. Also some plants show antidiarrhoeal properties by their antimicrobial activities (DiCarlo et al., 1993; llyas et al., 1995). The extract of Annona senegalensis was shown to exhibit good antibacterial activity when tested against Proteus mirabilis, Pseudomonas aeruginosa, Staphylococcus aureus and Escherichia coli. (Harami et al., 2005). The ability of the extract to attenuate the spontaneous contraction of rabbit ileum contraction and that induced by histamine and acetylcholine support the traditional use of the plant in controlling diarrhoea. The extract of Annona senegalensis, at the dose rate of $10 \mathrm{mg} / \mathrm{kg}$, significantly $(p<0.05)$ reduced the length covered by the standard charcoal meal in the gastrointestinal tract (GIT) of mice by $23.70 \%$. This value was higher than that of $19.69 \%$ produced by administration of loperamide (a standard antidiarrhoeal agent) at a dose of $1 \mathrm{mg} / \mathrm{kg}$.

The extract of Annona senegalensis concentration-dependently inhibited the spontaneous contractions of the isolated rabbit ileum. The results demonstrated that the crude methanol extract of Annona senegalensis bark induced a graded relaxation of the smooth muscle of the gastrointestinal tract, the severity of which depended on the concentration of the extract. According to Brunton (1996), the property of reducing intestinal contractions is demonstrated by most antidiarrhoeal agents, and this helps in preventing excessive loss of fluid and ingesta. The contractile effects of acetylcholine and histamine on isolated rabbit ileum were attenuated or abolished by the extract in a concentration dependent fashion. It is likely that the extract was acting as an antagonist of either neurotransmitter to block their effect by preventing the release of $\mathrm{Ca}^{2+}$ from the cisternae and hence its entry into the cell to activate smooth muscle contraction (Horowitz et al., 1996). 
In conclusion, the study showed that the methanol extract possesses an antidiarrhoeal effect. Further studies are required to completely understand the mechanisms of the extract antidiarrhoeal action, and to isolate the active component(s) in the crude extract.

\section{Acknowledgements}

The authors would like to thank Messrs I.A Orokpo, E. Nwosu, A.O. Abah and D.D. Dagai of the Department of Veterinary Physiology and Pharmacology, A.B.U, Zaria, and Mallam Ibrahim Adamu of the Department of Pharmacology and Clinical Pharmacy, A.B.U, Zaria, for their technical support.

\section{References}

1. Abubakar, M.S., Musa, A.M., Ahmed, A., Hussaini, I.M., 2007. The perception and practice of traditional medicine in the treatment of cancers and inflammations by the Hausa and Fulani tribes of northern Nigeria. Journal of Ethnopharmacology 111, 625-629.

2. Agunu, A., Yusuf, S., Andrew, G.O., Zezi, A.U., Abdurahman, E.M., 2005. Evaluation of five medicinal plants used in diarrhoea treatment in Nigeria. Journal of Ethnopharmacology 101, 27-30.

3. Amos, F.K., Okwusaba, K., Gamaniel, P., Akah, P., Wembebe, C., 1998. Inhibitory effects of the aqueous extracts of Pavetta crassipes leaves on gastrointestinal and uterine smooth muscle preparation isolated from rabbit, guinea-pig and rats. Journal of Ethnopharmacology 60, 209-212.

4. Audu, R., Umilabug, S.A., Renner, J.K., Awodiji, J.A., 2000. Diarrhoea management. Journal of Nigerian Infection Control Association 3, 15.

5. Aye-Than, H.J., Kukarni, Wut-hmone., Tha, S.J., 1989. Antidiarrhoeal efficacy of some Burmese indigenous drug formulations in experimental diarrhoeal test models. Journal Crude Drug Research 27, 195-200.

6. Brain, K.R., Turner, T.D., 1975. The Practical Evaluation of Phytopharmaceuticals. Wright-Scientechnica, Bristol, pp. 10-30.

7. Branson, K.R., Gross, M.E., 2001. In: Adam, H.R. (Ed.), Opioid Agonists and Antagonists. Veterinary Pharmacology and Therapeutics, 8th ed. lowa State University Press, Ames, pp. 268-298.

8. Brunton, L.L., 1996. Agents for control of gastric acidity and treatment of Peptic ulcers. In: Goodman and Gilman's the Pharmacological Basis of Therapeutics, 9th ed. McGraw-Hill, New York, pp. 901-915.

9. Burkill, H.M., 1985. The plants of west tropical Africa. families A-D 1, 103-105.

10. Dalziel, J.M., 1955. The Useful Plants West Tropical Africa. Crown Agents, London, p. 510.

11. DiCarlo, G., Autore, G., Izzo, A., 1993. Inhibition of intestinal motility and the secretion by flavonoids in mice and in rats: structural activity relationship. Journal of Pharmacy and Pharmacology 45, 1054-1059.

12. Fontaine, O., 1988. Bacterial diarrhoea and treatment. The Lancet 331, 1234-1235.

13. Harami, M.A., Abayeh, O.J., Agho, M.O., Abdullahi, A.L., Uba, A., Dukku, H.U.,Wufem, B.M., 2005. An ethnobotanical survey of Bauchi State herbal plants and their antimicrobial activity. Journal of Ethnopharmacology 99, 1-4.

14. Horowitz, A., Menice, C.B., Laporte, R., Morgan, K.G., 1996. Mechanisms of smooth muscle contraction. Physiological Reviews 76, 967-1003.

15. Ibrahim, M.A., Nwude, N., Ogunsusi, R.A., Aliu, Y.O., 1983. Screening of West African Plants for Anthelmintic Activity, 17. International Livestock Centre for Africa (ILCA), Bulletin, Addis Ababa, Ethiopia, pp. 19-22.

16. Ilyas, M., Haruna, A.K., llyas, N., 1995. Plant constituents with antidiarrhoeal properties. Bulletin of Science Association of Nigeria 10, 5-12.

17. Longanga Otshudi, A., Vercruysse, A., Foriers, A., 2000. Contribution to the ethnobotanical, phytochemical and pharmacological studies of traditionally used medicinal plants in the treatment of dysentery and diarrhea in Lomela area, Democratic Republic of Congo (DRC). Journal of Ethnopharmacology 71, 411-423.

18. Longe, R.L., Dipiro, J.T., 1992. Diarrhoea and constipation. In: Dopiro, J.T., Talbert, R.L., Hayes, P.E. (Eds.), Pharmacotheraphy. A Pathophysiologic Approach, 2nd ed. Elsevier, New York, pp. 566-578. 
19. Lorke, D., 1983. A new approach to practical acute toxicity testing. Archives of Toxicology 54, 275-287.

20. Macander, P.J., 1986. Flavonoids affect acetylcholine, prostaglandin $E$ and antigenmediated smooth muscle contraction. Progress in Clinical Biological Research 213, 489-492.

21. Nwude, N., Ibrahim, M.A., 1980. Plants used in traditional veterinary practice in Nigeria. Journal of Pharmacology and Therapeutics 3, 261-273.

22. Palombo, E.A., 2005. Phytochemicals from traditional medicinal plants used in the treatment of diarrhoea: modes of actions and effects on intestinal function. Phytotherapy Research 20, 717-724.

23. Rahman, M.A.,Wilcock, C.C., 1991.Areport on flavonoid investigation in some Bangladesh Asclepiads. Bangladesh Journal of Botany 20, 175-178.

24. Rang, H.P., Dale, M.M., Ritter, J.M., Moore, P.K. (Eds.), 2003. The Gastrointestinal Tract. Pharmacology, 5th ed. Churchill, Livingstones, Edinburgh, pp. 367-379 (Chapter 24).

25. Sofowora, A., 1993. Standardization of herbal medicine. In: Medicinal Plants and Traditional Medicine in Africa. Spectrum Books Limited, Lagos, Nigeria, pp. 56-61.

26. Snyder, J.D., Merson, M.H., 1982. The magnitude of the global problem of acute diarrhoeal disease: a review of active surveillance data. Bulletin of theWorld Health Organisation 60, 604-613.

27. Viswanathan, S., Thirugnana, S.P., Bapha, J.S., 1984. Flavonoid induced delay in the small intestinal transit. Possible mechanism of action. Archives Internationales Pharmacodynamie et de Therapie 270, 151-157.

Table 1

Effect of extract and loperamide on the gastrointestinal transit of charcoal meal (CM) in mice

\begin{tabular}{|lllll|}
\hline Treatment & No. of animals & Dose $(\mathrm{mg} / \mathrm{kg})$ & Mean length traversed by CM in $\mathrm{cm} \pm$ S.E.M. & \% reduction in length traversed by CM \\
\hline AS & 5 & 10 & $28.06 \pm 1.03 \mathrm{a}$ & 23.700 \\
AS & 4 & 100 & $37.45 \pm 1.05 \mathrm{~b}$ & -0.018 \\
AS & 5 & 1000 & $38.78 \pm 0.59 \mathrm{~b}$ & -5.760 \\
AS & 5 & 2900 & $39.54 \pm 0.18 \mathrm{~b}$ & -7.500 \\
NS & 5 & $5 \mathrm{ml} / \mathrm{kg}$ & $36.78 \pm 0.59 \mathrm{~b}$ & 0.000 \\
Loperamide & 5 & 1 & $29.54 \pm 0.80 \mathrm{a}$ & 19.69 \\
\hline
\end{tabular}

AS, Annona senegalensis; NS, normal saline; CM, charcoal meal.

Means with different letters differ significantly $(p<0.05)$.

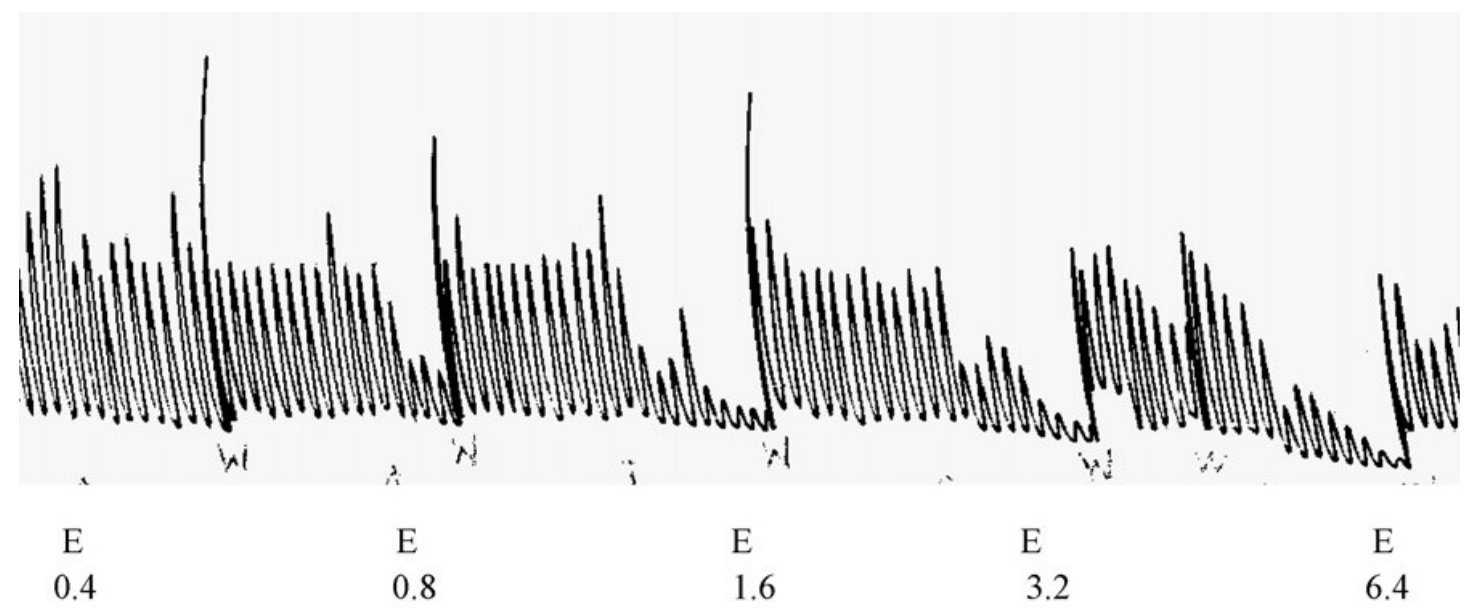

Fig. 1. Effect of various concentrations $(\mathrm{mg} / \mathrm{ml})$ of extract $(E)$ on spontaneous contraction of isolated rabbit ileum. 


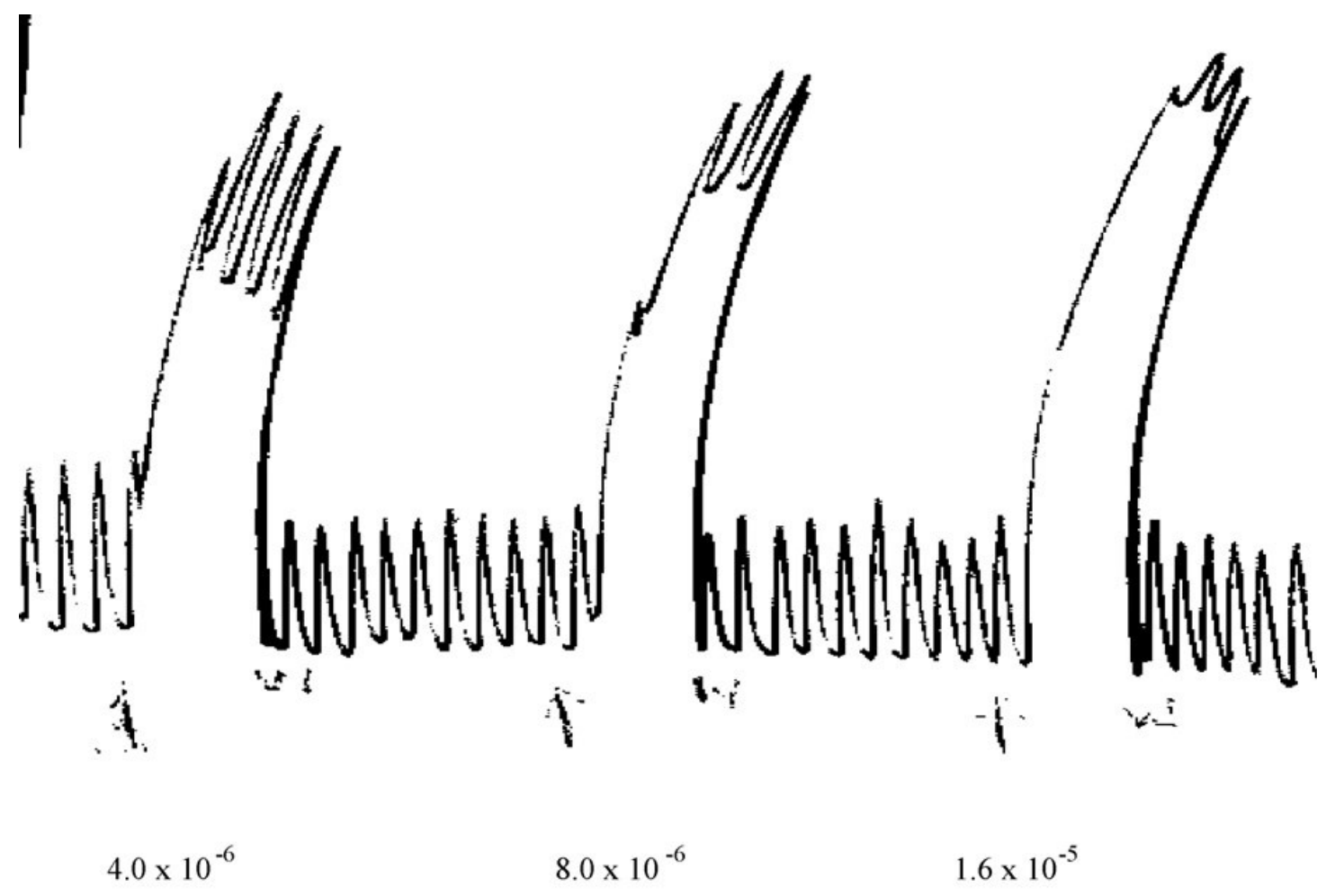

Fig. 2. Effects of varying concentrations $(\mathrm{mg} / \mathrm{ml})$ of acetylcholine $(\mathrm{ACh})$ on contraction of isolated rabbit ileum.

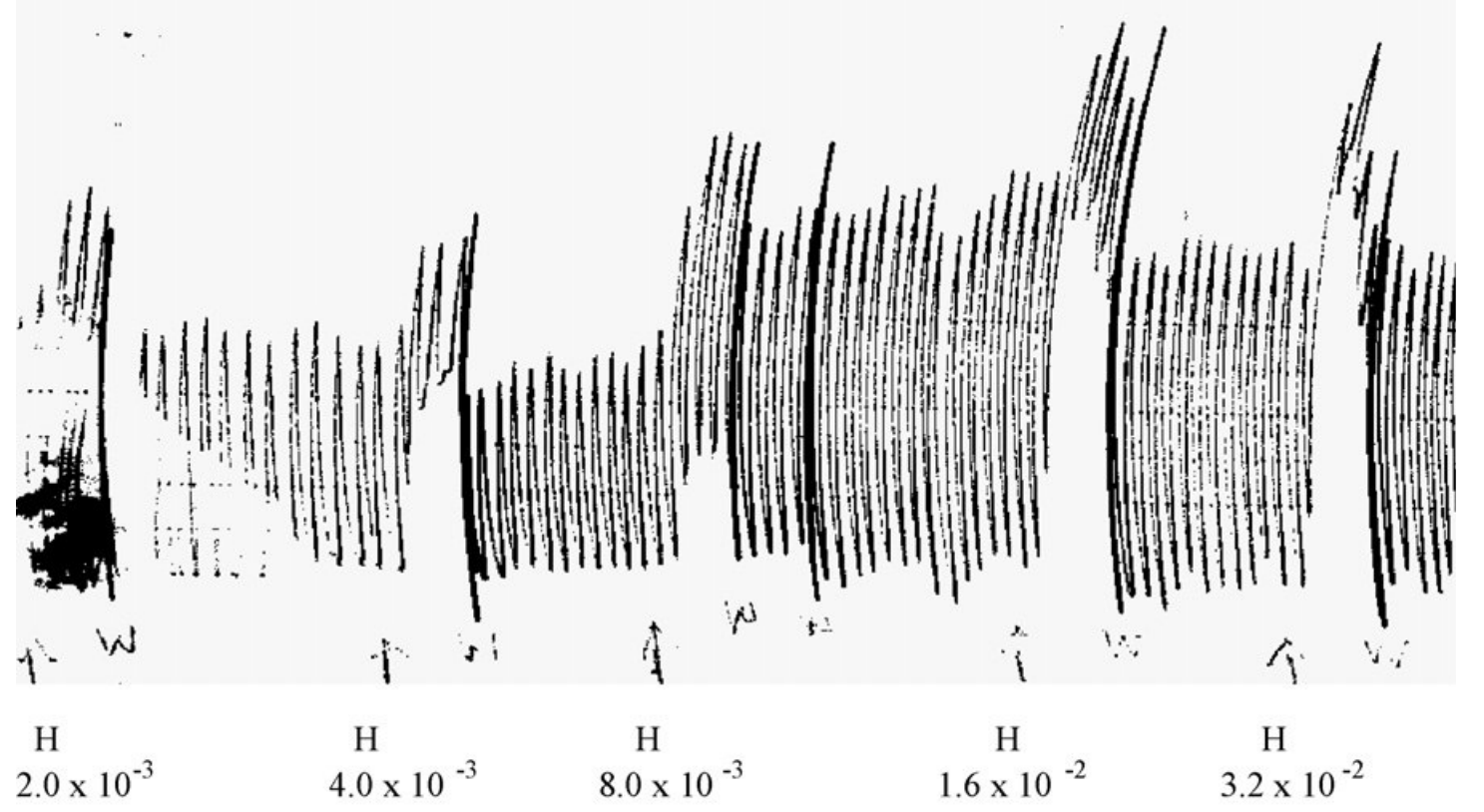

Fig. 3. Effects of varying concentrations $(\mathrm{mg} / \mathrm{ml})$ of histamine $(\mathrm{H})$ on contraction of isolated rabbit ileum. 


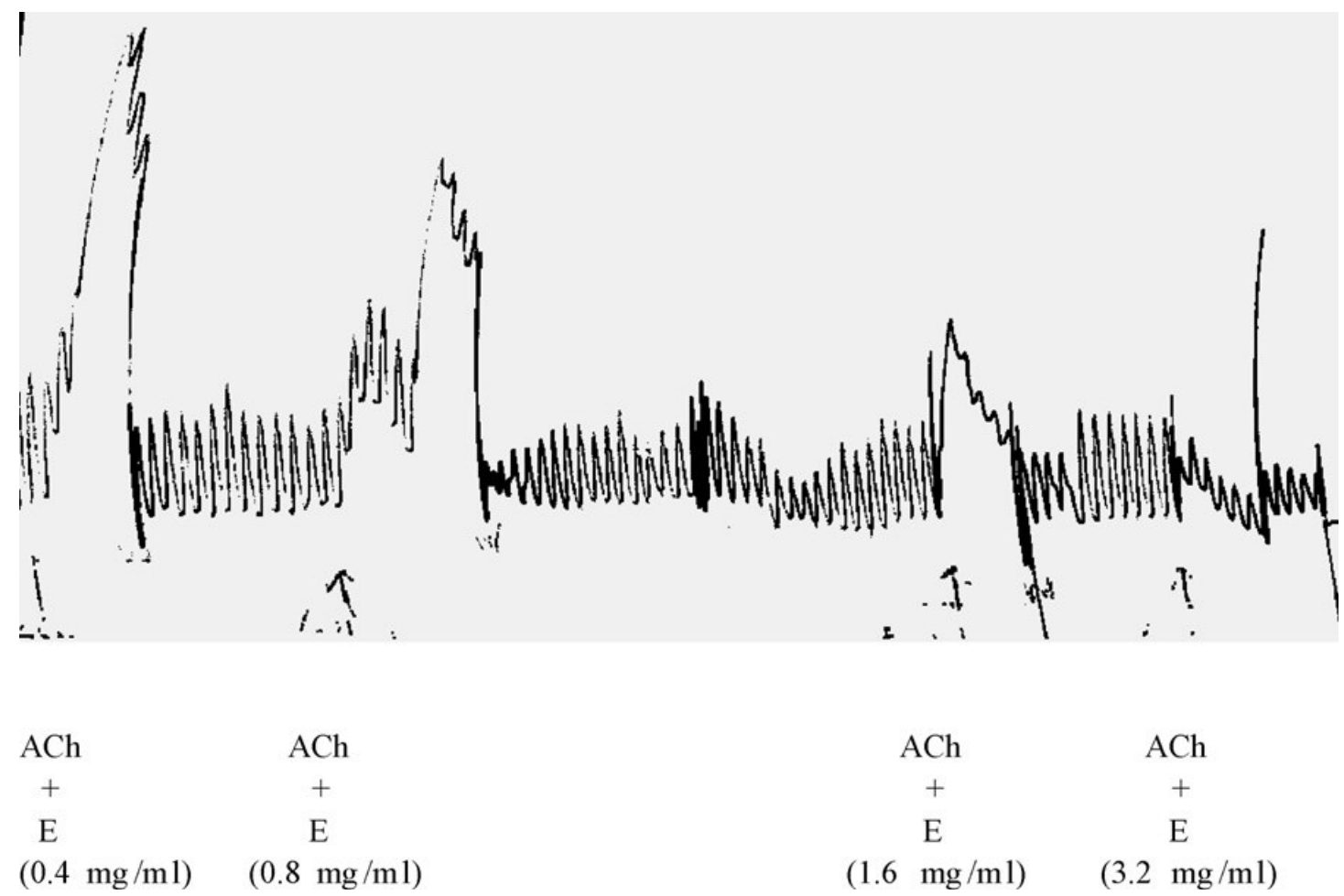

Fig. 4. Combined effects of varying concentrations of extract (E) and acetylcholine (ACh, $8.0 \times 10-6 \mathrm{mg} / \mathrm{ml}$ ) on isolated rabbit ileum.

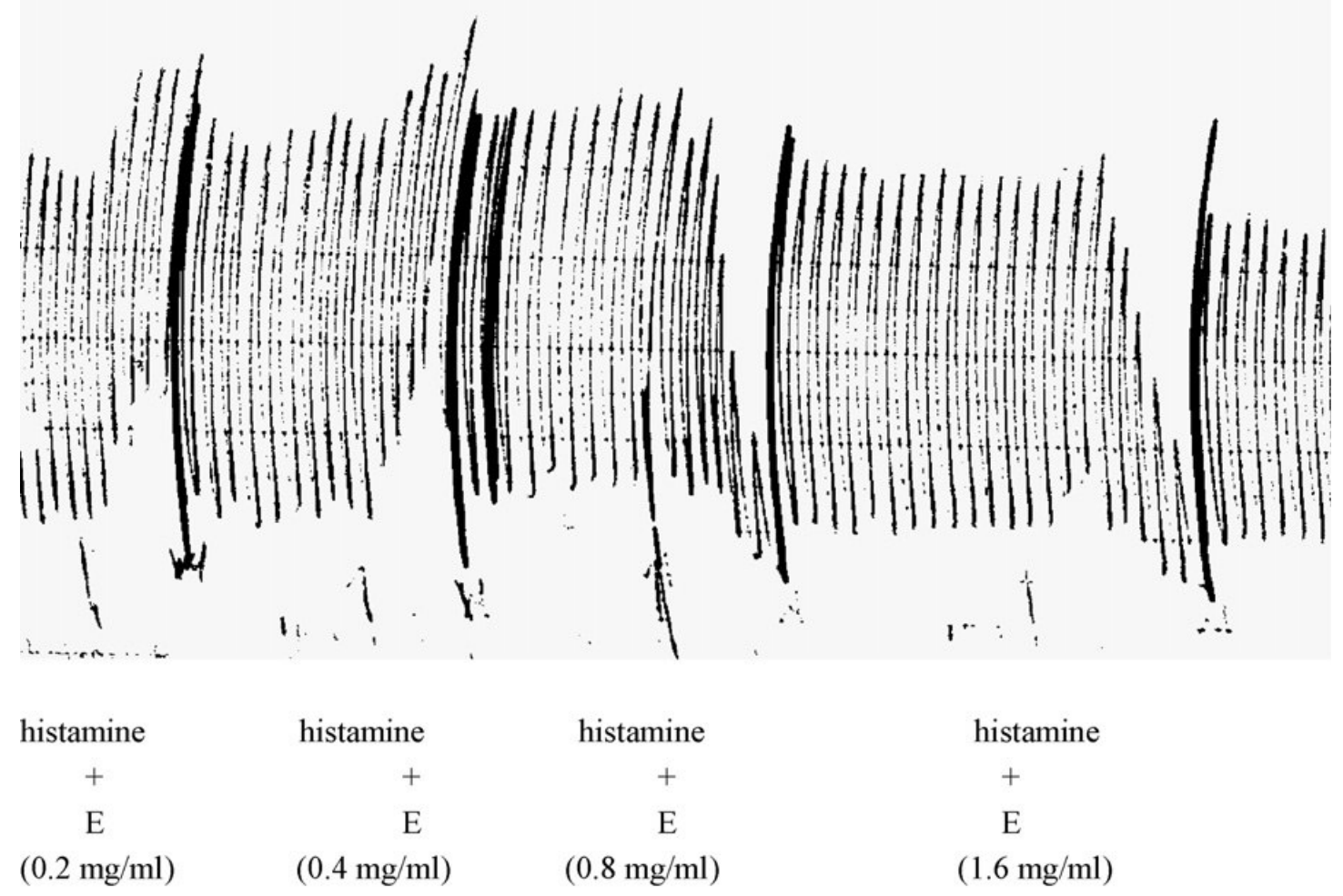

Fig. 5. Combined effects of varying concentrations of extract (E) and histamine $(4.0 \times 10-3$ $\mathrm{mg} / \mathrm{ml}$ ) on isolated rabbit ileum. 